\title{
街区公園における利用者評価による清掃品質管理手法に関する研究 A STUDY ON THE CLEANING QUALITY MANAGEMENT SYSTEM BY USERS' EVALUATION IN BLOCK PARKS
}

\author{
佐藤隆 良*, 杉田 洋**, 村川三郎***, 西名大作***, 平賀 慎***** \\ Takayoshi SATO, Hiroshi SUGITA, Saburo MURAKAWA, \\ Daisaku NISHINA and Makoto HIRAGA
}

\begin{abstract}
In this paper, we propose the customer-driven evaluation method for the quality of cleaning works. And further, as the case study toward to the introduction of this method, we apply it to the number of Block parks. Firstly, our research was conducted about points visitors to Block parks focus their attention on when they assess the quality of cleaning works, and the result showed that seven items were essentials, i.e. "open space", "rest room", "benches", "trees", "play equipment", "sand pool" and "dust bin". Secondly, 3-level assessment criteria for the quality of cleaning works on each seven item were prepared. In line with criteria prepared, assessments for the quality of cleaning works were conducted. Analyzing results of above assessment, visitors' demanded quality level, and the degree of visitors' satisfaction with current management condition for cleaning work, we examined the evaluation method for the quality of cleaning works in the maintenance of Block parks.
\end{abstract}

Keywords : Block parks, Evaluation points, Present condition evaluation for the quality of cleaning, Cleaning demand 街区公園, 評価のポイント，清掃品質の現状評価，清掃要求度

1. 序

都市部への人口集中にともなう環境悪化が問題となっている近年、 公園や緑地、広場といった屋外共用空間は、防災上の効果だけでは なく、地域社会の活性化を担う重要な要素である。なかでも街区公 園は、誘致距離・規模共に最小の都市公園であることから、近隣住 民にとって身近な鳃いの空間」として広く親しまれている。しかし ながら、これらの公園を維持するためには、地方自治体や地域住民 による清掃や施設の保全、または廃棄物の回収などの維持管理業務 が必要となる。

施設管理の分野に目を向けるならば、近年、施設の維持管理計画 を「戦略・計画」、「プロジェクト管理」、「運営維持」、「評価」といっ た一連のサイクルで捉え、「評価」段階において、「品質」、財務」、「供 給」それぞれの視点に基づく分析を実施し、その分析結果を以降の維 持管理計画に反映させる Facility Management（以下、FM と記す）が 取り入れられている。このような背景の下、平成 16 年 8 月、東京都 は、公園の維持管理・運営計画に FM の概念を取り入れ、定期的に 公園利用者、および近隣住民による評価を実施し、その結果に基づ

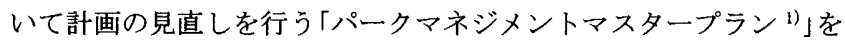
策定しており、利用者の要求に沿った公園づくりを目指している。 公園の維持管理形態に関する研究、公園の評価に関する研究はこ
れまでにも様々な視点から行われている。 前者の研究として、根来ら ${ }^{2)}$ は、地域住民による公園管理に対す る参加協力の形態、および各団体の性格を明らかにしている。また 井上ら ${ }^{3)}$ は、街区公園を対象として、行政、近隣住民、来訪者にお ける公園管理への関わり方を示したうえで、それぞれの問題点を抽 出し、空間活用に向けた管理方法の計画課題を明らかにしている。 そして樋野ら ${ }^{4)}$ は、公園利用において、犯罪不安に影響する要因を 明らかにしたうえで、不安要因改善に向けた住民による公園管理活 動の効果について分析している。

後者の研究として、塚田ら ${ }^{5)}$ は、小公園を対象として、その特性 を住民意識より構造的に捉え、公園の総合評価を階層的に分析し、 魅力ある公園整備を実現するための検討を行っている。また上杉ら ${ }^{6)}$ は、犯罪不安感を含めた公園の利用選択要因について、利用者意 識からみた各要因の重要度を明らかにしたうえで、利用者属性によ る犯罪不安感への意識の違いについて分析している。

また、維持管理、およびその評価に関する研究において、研究対 象を建物としたものでは、例えば清澤ら ${ }^{7)}$ 、坂下ら ${ }^{8)}$ は、施設の環 境管理に対する改善や、利用者の快適感・満足度の向上を図るうえ での指標となる評価基準の把握を目的として、「室内基本項目」、健 康・快適性」、「建物固有機能」、建築の支援機能」、「経済性」に関す

\footnotetext{
* サトウファシリティーズコンサルタンツ

**広島工業大学環境学部 講師・博士 (工学)

***広島大学大学院.工学研究科 教授.工博

**** 広島大学大学院. 工学研究科 助教授 $\cdot$ 博士 (工学)

***** 広島大学大学院・工学研究科 大学院生
}

Sato Facilities Consultants, Inc.

Lect., Faculty of Environmental Studies, Hiroshima Institute of Technology, Dr. Eng.

Prof., Graduate School of Engineering, Hiroshima Univ., Dr. Eng.

Assoc. Prof., Graduate School of Engineering, Hiroshima Univ., Dr. Eng.

Graduate Student, Graduate School of Engineering, Hiroshima Univ. 
るアンケート調查を居住者・建物管理者双方に対して実施し、収集 したデータに基づき、その後の維持管理計画について検討している。 また筆者らは既往の研究 ${ }^{9}$ において、庁舎における維持管理のなか でも、清掃管理に着目し、FM サイクルに基づく在室者による清掃 品質評価手法について検討している。

しかしながら、公園に関する既往研究において、清掃管理に対す る評価を FMサイクルに基づいて論考した研究はみられない。

そこで本研究では、街区公園における維持管理のなかでも清掃管 理に着目し、公園利用者による清掃品質の現状評価にあわせ、どの 程度きれいにしてほしいのかといった清掃要求に関する評価に基づ いた清掃品質管理を可能とするために、「利用者評価による清掃品質 管理手法」を提案する。図-1に本手法のフローを示す。また、本研 究においては本手法導入に向けたケーススタディではあるが、広島 市佐伯区に位置する複数の街区公園に対する本手法の適用から、図 -1 に示したフローに則り、「V.清掃品質の改善に関する検討」につ いても述べる。

具体的には、公園利用者に対して実施した『評価のポイント』に 関する調查により、遊具や便所といった、公園内に設置されている 施設等注1)のなかでも、公園利用者が清掃品質を評価する際に着目す るポイントを把握する。つぎに評価の対象となる施設等を設定し、 それぞれの対象について 3 段階による清掃品質の評価基準を作成す る。さらに、その評価基準により調査を実施し、現在の清掃品質に 対する評価（以下、「現状評価」）、要求する清掃品質（以下、「清掃 要求度」)、および現在の清掃管理状況に対する満足度を明らかにし たうえで、清掃品質の改善について検討する。

\section{2. 清掃品質管理手法の概要}

図-1のなかで、実線で示したフローは、対象施設におけるi）「評 価対象」、ii）「評価項目」、iii）「評価基準」がすでに設定されている場 合のフローである。しかしながら、i）・ii）・iii）が設定されていな い場合、または明確な清掃仕様が作成されておらず、その作成に関 して検討する場合は、点線で示したフローにより、i）・ii）・iii） それぞれに関する検討が必要となる。

以下に、各段階における検討内容をそれぞれ示す。

「I、『評価のポイント』の把握」ヒアリング調査により、利用 者が清掃品質の評価を行う際に「着目寸る対象（以下、「評価対 象」）」、「対象のなかで特に注目する籄所（以下、「評価箇所」）」、 および「箇所における污れの種類（以下、「污れの種類」）」、すな わち公園を評価する際の『評価のポイント』を把握する。

「II. 「評価対象」・「評価項目」の設定」I，の結果から、「評価対

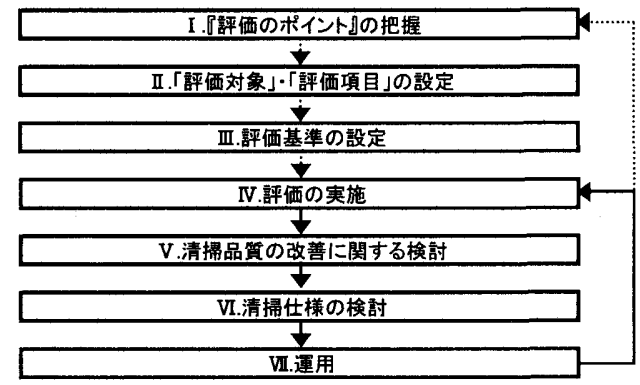

図-1 利用者評価による清掃品筫管理手法のフロー
象」、および評価項目」注2)を設定する。

「III. 評価基淮の設定」II.において得られた知見に基づき、評 価対象それぞれについて 3 段階による評価基準を作成する。

「IV. 評価の実施」調査対象公園における利用者に対し、III. III. に基づいて作成した調查票により、現在の清掃品質に対する現状 評価、清掃要求度、および清掃管理状況に対する満足度について それぞれ評価を求める。

「V，清掃品質の改善に関する検討」ここでは、利用者による 現在の清掃品質に対する現状評価、および清掃要求度に関する評 価結果に基づき分析を進める。すなわち、現状評価と清掃要求度 の間に乘離がある場合は、清掃品質の改善に向けた検討が必要と なることを意味する。またここでは、清掃管理状況に対する満足 度に関する分析から、清掃品質の改善について、その優先度も明 らかにする。

以上、図-1に則り本手法の流れを示したが、本手法適用の目的は 「VI. 清掃仕様の検討 1 段階で必要となる知見を得ることにある。

\section{3. 施設特性による街区公園の類別に関する検討}

本研究で調查対象地域とした広岛市佐伯区には 140 の街区公園が 存在する。都市公園法 ${ }^{10)}$ によれば、街区公園は、「街区内に居住す る者が容易に利用することができるように配置し、その数地面積は、 0.25ha を標準として定める」とされている。しかしながら、同区内 に位置する街区公園の面積は、0.01〜0.98ha の間に分布しており、 遊具、便所といった施設等の設置状況も公園により様々である。

本手法においては公園内に存在する施設等のなかでも、公園利用 者が清掃品質を評価する際に特に着目するものをそれぞれ評価対象 と位置付けて評価を行うことから、整備状況の異なる公園に対して 共通の評価基準を適用することは困難である。

ここでは本手法適用にあたり、それぞれの整備状況に沿った評価 基潐の作成を目的として、整備状況により街区公園を類型化する。

\section{1 街区公園の施設特性の把握}

同区内に位置する 140 の街区公園のうち、1,000 2, $500 \mathrm{~m}^{2}$ の面積 を有する 69 公園を対象として、2005 年 9 月中旬から 10 月上旬にわ たり、調查員が直接公園に来訪し、観察調査を実施した。各種設置 施設の集計結果を表-1 に示す。

A. 敷地状況をみるならば、「面積」では $1,500 \mathrm{~m}^{2}$ 未満が全体の約 5 割を占め、「敷地の舗装状況」では、全面裸地もしくは裸地に芝生を 配した仕上げが 8 割以上を占める。また「便所」は、約 6 割の公園に 設置されている。

B. 器具設置状況では、「ベンチ」は 69 の公園すべてに、「街灯」、水 飲み場」、「柵」が 9 割以上の公園に設置されている。

また、C. 遊具設置状況では、「摇動式遊具小、「滑走式遊具」が 8 割 以上の公園に設置されている。

\section{2 街区公園の類型化}

街区公園の施設特性から 69 公園を類型化するため、表-1 に示し た施設特性のなかでも、サンプル数に偏りが小さい「面積」、「100 $\mathrm{m}^{2}$ あたりの樹木数」、「便所」、「パーゴラ・シェルター類」、「ごみ箱」、 「街灯」、喫煙所」、「ベンチの設置数」、防球ネット」、掃除用具庫」、 「遊具の種類」注 3)、「砂場」の 12 項目について、数量化理論第II類に 
よる解析を適用した。最大固有値と、つぎに大きな固有值を第 I 軸、 第 II 軸として各カテゴリーを布置した結果を図-2 に示す。

第 I 軸は「面積」のカテゴリーが軸に沿って布置されており、正側 に $1,500 \mathrm{~m}^{2}$ 以上の公園、負側に面積が $1,500 \mathrm{~m}^{2}$ 未満の公園が類別さ れている。これに対応して、他のカテゴリーとの関連をみるならば、 前者は「便所」「防球ネット」などの施設が設置されている「施設充実 型」公園であり、後者はそれらが設置されていない「施設空虚型」公園 であると解釈できる。

第II 軸は、「遊具の種類」との関連がみられ、他のカテゴリーと併 せて解釈するならば、正側には「遊具」や「ベンチ」の数が少なく、「パ ーゴラ」、ごみ箱」、砂場」も設置されていない「設備空虚型」公園が、 負側には、それらの設備が設置されており、「遊具」や「ベンチ」も比 較的多く設置されている「設備充実型」公園が類別されている。

つづいて、第 I 軸、および第 II 軸のサンプルスコアを用いて、ウ オード法によるクラスター分析を行った。結果をサンプルスコアの 布置と併せて図-3に示す。

図-3 をみるならば、調査対象である 69 の公園は、大きく 4 つの 公園群（距離 5.0 以上）に分類されることから、各公園群における 施設特性により、A、B、C、D グループをそれぞれ「広場的公園小、「空
地的公園」、「遊戲公園」、「総合的公園」と解䣋する。

\section{4. 調查概要}

\section{1 『評価のポイント』に関する調査}

ここでは、図-1に示した「 I．『評価のポイント』の把握」に関す る調查概要を示す。なお本研究では、D グループ：「総合的公園」に 属する公園を対象として本手法を適用する。

\section{（1） 調查対象公園の概要}

調查対象公園として、図-3のDグループ：「総合的公園」に属する 15 公園のなかでも、調查期閒（11月上旬）において比較的利用者が

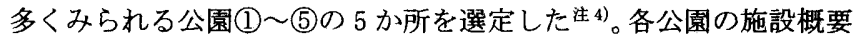
を表-2に示す。

「便所」、砂場」は 5 公園す心゙てに、「パーゴラ・シェルター類」、ご み箱」、「街灯了、「防球ネット」、「掃除用具庫」、「水飲み場」は、5 公 園のうち 4 公園に設置されている。また遊具は、「摇動式遊具」、「滑 走式遊具」が、 5 公園すべてに設置されており、「䜿垂式遊具」も 4 公 園に設置されていることから、これら 5 公園の施設特性はほぼ共通 しているといえる。

（2）ヒアリング調査の概要

\begin{tabular}{|c|c|c|c|}
\hline & アイテム & カテブリ- & サンプル数 \\
\hline 1 & 面樻 & $1500 \mathrm{~m}^{2}$ 未满 & 35 \\
\hline & & $1500 \sim 2000 \mathrm{~m}^{2}$ & 22 \\
\hline & & $2000 \mathrm{~m}^{\prime}$ 以上 & 12 \\
\hline \multirow[t]{3}{*}{2} & 用途地域 & 住居専用地域 & 54 \\
\hline & & 住居地域 & 13 \\
\hline & & その他 & 2 \\
\hline \multirow[t]{4}{*}{3} & 数地の㩰装状況 & 裸地 & 30 \\
\hline & & 裸地＋芝生 & 25 \\
\hline & & 裸地十芝生+棟瓦数 & 6 \\
\hline & & その他 & 8 \\
\hline \multirow[t]{2}{*}{4} & 數地の頓斜・ & 有 & 8 \\
\hline & レベル差 & 無 & 61 \\
\hline \multirow[t]{3}{*}{5} & 入りロに接する & 1方向 & 20 \\
\hline & 道路数 & 2方向 & 43 \\
\hline & & 3方向 & 6 \\
\hline \multirow[t]{3}{*}{6} & 100m² あたりの & 1本末満 & 12 \\
\hline & 樹木数 & 1 3本 & 45 \\
\hline & & 3本以上 & 12 \\
\hline \multirow[t]{2}{*}{7} & 駐車场 & 有 & 0 \\
\hline & & 無 & 69 \\
\hline \multirow[t]{2}{*}{8} & 集会所 & 有 & 7 \\
\hline & & 無 & 62 \\
\hline \multirow[t]{2}{*}{9} & 便所 & 有 & 43 \\
\hline & & 無 & 26 \\
\hline
\end{tabular}

表-1 各種設置施設の集計結果

\begin{tabular}{|c|c|c|c|}
\hline & アイテム & カテゴリー & サンプル数 \\
\hline \multirow[t]{2}{*}{1} & パーコラ. & 有 & 32 \\
\hline & シェルター類 & 無 & 37 \\
\hline \multirow[t]{2}{*}{2} & ごみ箱 & 有 & 48 \\
\hline & & 無 & 21 \\
\hline \multirow[t]{2}{*}{3} & 街灯 & 有 & 62 \\
\hline & & 無 & 7 \\
\hline \multirow[t]{2}{*}{4} & 猰煙所 & 有 & 4 \\
\hline & & 無 & 65 \\
\hline \multirow[t]{3}{*}{5} & ベンチの設置数 & 5未満 & 26 \\
\hline & & $5 \sim 10$ & 35 \\
\hline & & 10以上 & 8 \\
\hline \multirow[t]{2}{*}{6} & 防球ネット & 有 & 18 \\
\hline & & 無 & 51 \\
\hline \multirow[t]{2}{*}{7} & 揌除用異庫 & 有 & 35 \\
\hline & & 無 & 34 \\
\hline \multirow[t]{2}{*}{8} & 看板類 & 有 & 61 \\
\hline & & 無 & 8 \\
\hline \multirow[t]{2}{*}{9} & 水飲み埥 & 有 & 65 \\
\hline & & 無 & 4 \\
\hline \multirow[t]{2}{*}{10} & 莗止め & 有 & 53 \\
\hline & & 無 & 16 \\
\hline \multirow[t]{2}{*}{11} & 珮 & 有 & 68 \\
\hline & & 無 & 1 \\
\hline
\end{tabular}

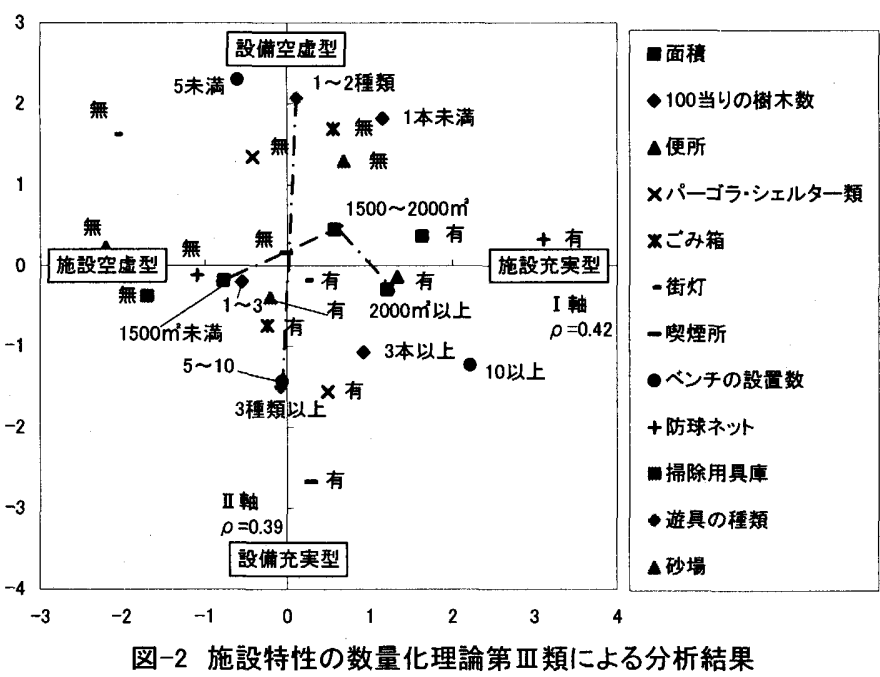

図-2 施設特性の数量化理論第正類による分析結果

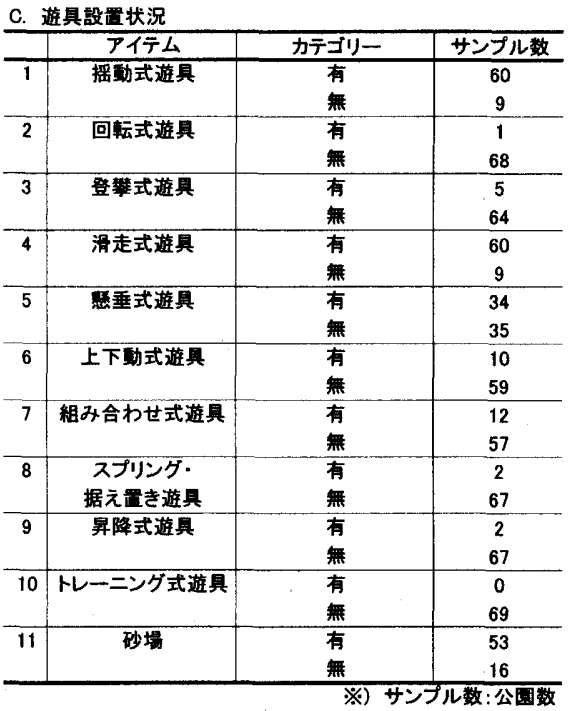

※)遊具の分類は善考文献11による。

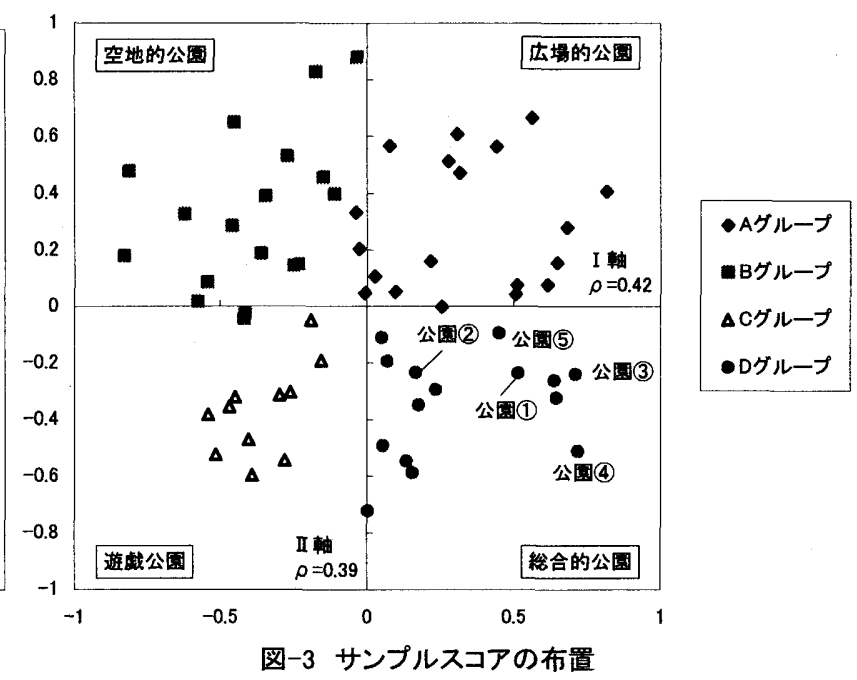


調查は 2005 年 11 月上旬の 4 日間にわたり、対象公園を訪れた 18 歳以上の利用者注5) に対して面接形式により実施した ${ }^{\text {注 }}$ )。各公園に おける有効回答は、公園(1)で 33 票、公園(2)で 29 票、公園(3)で 23 票、公園(4)で 13 票、公園(5)で 30 票の計 128 票である。

ヒアリングには、調查の円滑化、および調査員の違いによる回答

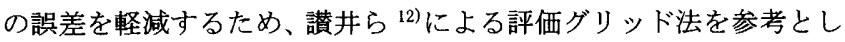
た。表-3にヒアリングの手順を示す。

ヒアリングの具体的な方法としては、まず表-3の設問 1)より、現 在の清掃管理状況についての主観的な評価を求める。つぎに設問 2)、 3)では、回答者が来訪経験のある公園について、その公園名を求め る。設問 4)では、設問 3)で挙げられた公園と調査対象公園との比較 評価を行い、清掃品質の優劣について判断を求める。そして設問 5) では、設問 4)において判断を下した要因について回答を求め、利用 者の視点による『評価のポイント』を明らかにする。すなわち、設 問 3)で挙げられた比較対象公園と比心゙、調查対象公園の方が「きれ い」または「污いと感じたなら、「調査対象公園において、何(「評価 対象」）の、何処（「評価項目」）が、比較対象公園と比べてどのよう になっている(「污れの種類」）から」といった回答を求める。

\section{2 清掃品質の評価に関する調查}

ここでは、図-1に示した「IV.評価の実施」に関する調査概要につ いて述べる。

\section{（1）調查対象公園の概要}

調査対象公園は、表-2 に示した 5 公園のなかでも、調查期間（11 月下旬) において比較的多くの利用者がみられた公園(1) (3)の 3 公

表-2 調査対象公園における整備概要

\begin{tabular}{|c|c|c|c|c|c|}
\hline & 公圈(1) & 公国(2) & 公围(3) & 公园(4) & 公围(5) \\
\hline 票地面䅡 $\left(\mathrm{m}^{\prime}\right)$ & 1900 & 1500 & 1700 & 1000 & 1700 \\
\hline 䫓工年(年) & 1983 & 1996 & 1996 & 1992 & 1996 \\
\hline 用途地域 & 近膦商菜 & $\begin{array}{c}\text { 第2種中高雷 } \\
\text { 住居専用 }\end{array}$ & 第1種住居 & $\begin{array}{c}\text { 第1種低雷住 } \\
\text { 居軎用 }\end{array}$ & 第1種住居 \\
\hline 數地の哺装状況 & 裸地 & 裸地+芝生 & 裸地 & 裸地+芝生 & $\begin{array}{l}\text { 裸地+芝生+ } \\
\text { レンガ数き }\end{array}$ \\
\hline $100 \mathrm{~m}^{2}$ 当りの樹木数 & 2.6 & 4.9 & 3.1 & 7.6 & 1.1 \\
\hline パーゴラ・シェルター類 & 0 & & 0 & $\mathrm{O}$ & 0 \\
\hline ごみ箱 & 0 & 0 & 0 & 0 & \\
\hline 街灯 & & 0 & 0 & $\mathrm{O}$ & O \\
\hline \multicolumn{6}{|l|}{ 㬗煙所 } \\
\hline ベンチの僠数 & 12 & 10 & 7 & 16 & 7 \\
\hline 便所 & 0 & 0 & 0 & $\mathrm{O}$ & $\mathrm{O}$ \\
\hline 防球ネット & 0 & & $\mathrm{O}$ & 0 & 0 \\
\hline 掃除用具庫 & 0 & 0 & 0 & 0 & \\
\hline 水徝み场 & 0 & $\mathrm{O}$ & & 0 & $\mathrm{O}$ \\
\hline 摇動式遊具 & 0 & $\mathrm{O}$ & O & 0 & 0 \\
\hline \multicolumn{6}{|l|}{ 回転式遊具 } \\
\hline \multicolumn{6}{|l|}{ 登帮式遊具 } \\
\hline 滑走式遊具 & 0 & $\mathrm{O}$ & 0 & 0 & 0 \\
\hline 血垂式遊具 & $\mathrm{O}$ & $\mathrm{O}$ & 0 & 0 & \\
\hline 上下動式遊具 & 0 & & & & \\
\hline 組み合わせ式遊具 & 0 & 0 & 0 & & \\
\hline 据え置き遊具 & & & & & $\mathrm{O}$ \\
\hline 砂場 & 0 & 0 & $\mathrm{O}$ & 0 & $\mathrm{O}$ \\
\hline \multicolumn{6}{|l|}{ 栎降式遊具 } \\
\hline トレーニング式遊具 & & & & & \\
\hline その他の遊具 & & & & & \\
\hline
\end{tabular}

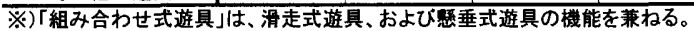

表-3 ヒアリングの手順

\begin{tabular}{|c|c|}
\hline 設問No. & 設問内容 \\
\hline 1) & $\begin{array}{l}\text { 調査対象公園の清掃状況について、「非常にきれい」、「ややきれい」、「やや污い」、 } \\
\text { 「非常に污い」の4段階で回答を求める。 }\end{array}$ \\
\hline 2) & 他の公園への来訪経験の有無を帚ねる。 \\
\hline 3) & 設問2)において「来訪経験有」の場合、その公園名について回答を求める゙け!。 \\
\hline 4) & 設問3)で挙げられた公園と、調査対象公園との比较評価を行う*1!。 \\
\hline 5) & 設問4)における評価要因についての回答を求める*2)。 \\
\hline
\end{tabular}

園とした注7)。

またこれら 3 公園では、清掃業者による委託清掃、および近隣住 民による清掃が並行して行われている。

前者の作業内容は、園内の目立つごみの回収にあわせ、ごみ箱の 中のごみを公園外に搬出する作業である。この作業は、公園(1)では 4 回/月、公園(2)、および(3)では 3 回/月の周期で実施されている。

後者の作業内容は、i ) 敷地内の拾い掃きなどの一般清掃、ii ) 法 面を除く部分の除草作業注 8) 2 作業である。またこれらの作業は近 隣住民により実施されていることから、各月における実施回数に若 干の違いが認められる。したがって、i )の実施回数を年間における 月平均で、ii）の実施回数を作業期間における月平均でみるならば、 公園(1)では i ) が約 5 回/月、ii ）が約 2 回/月、公園(2)では i )・ii) ともに約 1 回/月、公園(3)では i )が約 5 回/月、ii )が約 2 回/月の周 期で実施されている注 9 。

\section{（2）ヒアリング調査の概要}

調査は 2005 年 11 月下旬の 4 日間にわたり、対象公園を訪れた 18 歳以上の利用者注 5) に対して面接形式により実施した注6)。4 日間の 有効回答は公園(1)で 62 票、公園(2)で 56 票、公園(3)で 29 票の計 147 票である。

ヒアリングの内容は、大別して「属性に関する質問」、使用頻度」、 「満足度」、「現状評価」、「清掃要求度」の 5 グループの設問項目で構 成され、 7 頁 41 項目の設問からなる。

（i）「属性に関する質問」性別、年齢といった回答者属性と、来 訪頻度、滞在時間といった利用行動特性の 2 分類からなる。

(ii）「使用頻度」各「評価対象」の使用頻度について「よく利用す る」・「たまに利用する」・「ほとんど利用しないの3 段階でそれ ぞれ回答を求める。

（iii）「満足度」各「評価対象」の清掃管理状況に対する満足度につ いて「満足である」、やや満足である」、「゙ちらともいえない」、 「やや不満である」、「不満である」の 5 段階で回答を求める。

(iv)「現状評価」各「評価対象」における現在の清掃品質について、 「レベル1」〜「レベル 3」の 3 段階で評価を求める。

(v)「清掃要求度」各「評価対象」において、それぞれ要求する清 掃品質について、（iv）の場合と同様に「レベル 1」〜「レベル 3」 の 3 段階で回答を求める。

なお、「評価対象」、および(iv)・( ）における 3 段階の評価基準 についてはその設定方法も含め後述する。

\section{3 回答者属性}

回答者属性を表-4、利用行動特性を表-5 にそれぞれ示す。なお、 両表において「I．」列に示した值は 4.1「『評価のポイント』に関す る調査」、「IV.J列に示した値は 4.2 「清掃品質の評価に関する調査」 それぞれの回答者数を示す。

表-4 右端に示した、全体「I、」列をアイテムごとにみるならば、 「性別」では、男女の割合はほぼ同等であり、「年齢」では、50 代以上 が全体の約 4 割を占める。「職業」では、主婦、および会社員・公務 員の割合が高く、それぞれ全体の約 3 割を占める。

公園ごとにみるならば、「年齢」では、公園(1)において 20 代以下の 割合が他の公園と比べ高くなっている。「職業」では、公園(1)、(2)に おいては、主婦の割合が他の公園と比較して高く、全体の約 4 割を 占める。また「グループ構成」では、公園(1)、(2)において大人十子供 
の割合が高く、公園(4)、公園(5)においてはペット連れの割合が高い。

表-5 右端に示した、全体「I.」列をアイテムごとにみるならば、 「滞在時間」は、30 分未満が約 5 割を占め、「来訪目的」は、散歩、お よび遊戯がそれぞれ全体の約 4 割を占める。また、「来訪元」は自宅、 「来訪手段」は徒歩、「所要時間」は $1 \sim 10$ 分が多いことから、回答者 の多くは近隣住民であるといえる。公園ごとに特徽的な項目をみる なら、「来訪目的」において、公園(4)、(5)は、散歩の割合が他の公園 と比較して高くなっている。

また表-4、および表-5 それぞれの右端に示した、全体「IV.」列を アイテムごとにみるならば、「I．」列と比較して、「年輪」においては

表-4 回答者の属性

\begin{tabular}{|c|c|c|c|c|c|c|c|c|c|c|c|c|c|}
\hline \multirow{2}{*}{ アイテム } & \multirow{2}{*}{ カテゴリー } & \multicolumn{2}{|c|}{ 公園(1) } & \multicolumn{2}{|c|}{ 公園(2) } & \multicolumn{2}{|c|}{ 公園(3) } & \multicolumn{2}{|c|}{ 公園(4) } & \multicolumn{2}{|c|}{ 公園(5) } & \multicolumn{2}{|c|}{ 全体 } \\
\hline & & I. & IV. & I. & IV. & I. & IV & I. & IV. & I. & IV. & I. & IV. \\
\hline \multirow{3}{*}{ 性別 } & 男 & 13 & 28 & 10 & 28 & 10 & $\overline{15}$ & 7 & $\overline{-}$ & 21 & - & 61 & 71 \\
\hline & 女 & 20 & 34 & 19 & 28 & 11 & 12 & 6 & - & 8 & - & 64 & 74 \\
\hline & 未記入 & 0 & 0 & 0 & 0 & 2 & 2 & 0 & - & 1 & - & 3 & 2 \\
\hline \multirow{4}{*}{ 年齢 } & 20代以下 & 13 & 12 & 4 & 9 & 5 & 9 & 3 & - & 4 & - & 29 & 30 \\
\hline & 30 代 40代 & 9 & 35 & 17 & 20 & 6 & 13 & 4 & - & 8 & - & 44 & 68 \\
\hline & 50 代以上 & 10 & 15 & 8 & 27 & 10 & 7 & 6 & - & 18 & - & 52 & 49 \\
\hline & 未記入 & 1 & 0 & 0 & 0 & 2 & 0 & 0 & - & 0 & - & 3 & 0 \\
\hline \multirow{7}{*}{ 職業 } & 会社員·公務員 & 3 & 15 & 6 & 12 & 8 & 20 & 5 & - & 10 & - & 32 & 47 \\
\hline & 自営業 & 3 & 3 & 1 & 2 & 2 & 0 & 0 & - & 4 & - & 10 & 5 \\
\hline & 主㛿 & 13 & 26 & 13 & 23 & 7 & 3 & 2 & - & 6 & - & 41 & 52 \\
\hline & 学生 & 6 & 3 & 2 & 8 & 0 & 0 & 2 & - & 1 & - & 11 & 11 \\
\hline & パート・アルパイト & 3 & 5 & 2 & 2 & 2 & 3 & 2 & - & 1 & - & 10 & 10 \\
\hline & その地 & 4 & 9 & 5 & 9 & 2 & 3 & 2 & - & 7 & - & 20 & 21 \\
\hline & 末記入 & 1 & 1 & 0 & 0 & 2 & 0 & 0 & - & 1 & - & 4 & 1 \\
\hline \multirow{5}{*}{ 同伴者数 } & 自分ひとり & 7 & 18 & 3 & 19 & 7 & 8 & 2 & - & 16 & - & 35 & 45 \\
\hline & $2 人$ & 15 & 25 & 11 & 24 & 8 & 7 & 2 & - & 1 & - & 37 & 56 \\
\hline & 3 人以上 & 5 & 10 & 13 & 8 & 5 & 14 & 0 & - & 0 & - & 23 & 32 \\
\hline & ペット & 6 & 5 & 2 & 3 & 2 & 0 & 8 & - & 12 & - & 30 & 8 \\
\hline & 未記入 & 0 & 4 & 0 & 2 & 1 & 0 & 1 & - & 1 & - & 3 & 6 \\
\hline \multirow{5}{*}{ グループ栖成 } & 自分ひとり & 7 & 18 & 3 & 19 & 7 & 8 & 2 & - & 16 & - & 35 & 45 \\
\hline & 大人+子阱 & 18 & 35 & 15 & 16 & 8 & 7 & 1 & - & 0 & - & 42 & 58 \\
\hline & 大人のみ & 2 & 4 & 8 & 16 & 4 & 14 & 1 & - & 1 & - & 16 & 34 \\
\hline & ペット & 6 & 5 & 2 & 3 & 2 & 0 & 8 & - & 12 & - & 30 & 8 \\
\hline & 未記入 & 0 & 0 & 1 & 2 & 2 & 0 & 1 & - & 1 & - & 5 & 2 \\
\hline
\end{tabular}

※) I .」列:『評価のポイント』に関する調査、「IV.J列:清穆品筫の評価に関する調查

表-5 利用行動特性

\begin{tabular}{|c|c|c|c|c|c|c|c|c|c|c|c|c|c|}
\hline \multirow{2}{*}{ アイテム } & \multirow{2}{*}{ カテゴリー } & \multicolumn{2}{|c|}{ 公園(1) } & \multicolumn{2}{|c|}{ 公園(2) } & \multicolumn{2}{|c|}{ 公園(3) } & \multicolumn{2}{|c|}{ 公園(4) } & \multicolumn{2}{|c|}{ 公園(5) } & \multicolumn{2}{|c|}{ 全体 } \\
\hline & & I. & IV. & I. & IV. & I. & IV. & I. & IV. & I. & IV. & I. & IV. \\
\hline \multirow{4}{*}{ 来訪類度 } & 週1回末満 & 13 & 29 & 8 & 19 & 9 & 8 & 1 & $\overline{-}$ & 3 & - & 34 & 56 \\
\hline & 䓢 1 4回 & 10 & 23 & 15 & 25 & 7 & 5 & 5 & - & 10 & - & 47 & 53 \\
\hline & 週4回以上 & 10 & 9 & 6 & 12 & 7 & 16 & 6 & - & 17 & - & 46 & 37 \\
\hline & 未記入 & 0 & 1 & 0 & 0 & 0 & 0 & 1 & - & 0 & - & 1 & 1 \\
\hline \multirow{4}{*}{ 滞在時間 } & 30分未満 & 14 & 21 & 8 & 27 & 9 & 13 & 9 & - & 28 & - & 68 & 61 \\
\hline & 30分 1 時間 & 11 & 16 & 7 & 16 & 4 & 8 & 3 & - & 1 & - & 26 & 40 \\
\hline & 1時間以上 & 8 & 24 & 13 & 13 & 9 & 8 & 1 & - & 1 & - & 32 & 45 \\
\hline & 未記入 & 0 & 1 & 1 & 0 & 1 & 0 & 0 & - & 0 & - & 2 & 1 \\
\hline \multirow{10}{*}{ 来訪目的 } & 散歩 & 16 & 20 & 9 & 15 & 5 & 4 & 10 & - & 17 & - & 57 & 39 \\
\hline & 遊戯 & 17 & 28 & 16 & 21 & 11 & 5 & 2 & - & 1 & - & 47 & 54 \\
\hline & だんらん & 2 & 1 & 0 & 1 & 0 & 0 & 0 & - & 1 & - & 3 & 2 \\
\hline & 気分転换 & 6 & 9 & 3 & 5 & 0 & 2 & 2 & - & 1 & - & 12 & 16 \\
\hline & 食事 & 0 & 5 & 1 & 2 & 0 & 1 & 0 & - & 0 & - & 1 & 8 \\
\hline & 喫煙 & 2 & 1 & 2 & 2 & 3 & 14 & 1 & - & 0 & - & 8 & 17 \\
\hline & トイレ利用 & 0 & 1 & 0 & 1 & 0 & 3 & 0 & - & 6 & - & 6 & 5 \\
\hline & レクリエーション & 0 & 2 & 3 & 1 & 0 & 3 & 0 & - & 0 & - & 3 & 6 \\
\hline & その他 & 0 & 1 & 1 & 11 & 3 & 0 & 2 & - & 6 & - & 12 & 12 \\
\hline & 未記入 & 0 & 0 & 0 & 0 & 1 & 0 & 0 & - & 1 & $\ldots$ & 2 & 0 \\
\hline \multirow{3}{*}{ 来訪元 } & 自宅 & 26 & 46 & 22 & 37 & 18 & 11 & 13 & - & 21 & - & 100 & 94 \\
\hline & 自宅以外 & 7 & 15 & 5 & 18 & 4 & 18 & 0 & - & 8 & - & 24 & 51 \\
\hline & 未記入 & 0 & 1 & 2 & 1 & 1 & 0 & 0 & - & 1 & - & 4 & 2 \\
\hline \multirow{6}{*}{ 来訪手段 } & 徒歩 & 20 & 30 & 25 & 45 & 12 & 20 & 12 & - & 21 & - & 90 & 95 \\
\hline & 自家用車 & 4 & 11 & 3 & 5 & 6 & 8 & 1 & - & 4 & - & 18 & 24 \\
\hline & 自転車 & 8 & 18 & 1 & 4 & 2 & 1 & 0 & - & 2 & - & 13 & 23 \\
\hline & バイク & 1 & 3 & 0 & 2 & 1 & 0 & 0 & - & 1 & - & 3 & 5 \\
\hline & 公共交通機関 & 0 & 0 & 0 & 0 & 1 & 0 & 0 & - & 1 & - & 2 & 0 \\
\hline & 未記入 & 0 & 1 & 0 & 0 & 1 & 0 & 0 & - & 1 & - & 2 & 1 \\
\hline \multirow{5}{*}{ 所要時間 } & 1 10分 & 21 & 31 & 23 & 37 & 12 & 22 & 10 & - & 18 & - & 84 & 90 \\
\hline & 10 20分 & 11 & 20 & 4 & 14 & 6 & 3 & 3 & - & 5 & - & 29 & 37 \\
\hline & 20 30分 & 1 & 4 & 0 & 2 & 2 & 3 & 0 & - & 2 & - & 5 & 9 \\
\hline & 30分以上 & 0 & 6 & 1 & 3 & 1 & 1 & 0 & - & 2 & - & 4 & 10 \\
\hline & 未記入 & 0 & 1 & 1 & 0 & 2 & 0 & 0 & - & 3 & - & 6 & 1 \\
\hline
\end{tabular}

※)「I.J列:『評価のポイント』に関する調㚗，「IV.J列:清掃品筫の評価に関する調查
$30 \sim 40$ 代の割合が若干高く、「来訪目的」においては散歩の割合が低 くなっているものの、表-4、および表-5 ともに「I.」列と比較して 大きな差異がみられず、概ね同様の回答構成であることがわかる。

\section{5. 清掃品質評価基準に関する唡討}

ここでは、図-1に示した I ～～III. の各段階について検討する。具 体的には、『評価のポイント』に関する調査結果に基づき、利用者が 公園の清掃品質を評価する際の「評価対象」を明らかにしたうえで、 「評価項目」の設定を行い、これをもとに 3 段階による清掃品質評価 基準を作成する。

\section{1 『評価のポイント』の把握}

調查により、16 種の対象について計 275 の指摘を得た。ここでは 指摘された『評価のポイント』のなかでも、1 割以上の回答者から 指摘があった「評価対象」、それに対応する「評価箇所」、および「污れ の種類」を表-6 に示す。なお、公園(1)～(5)は、前述したとおり施設 特性がほぼ共通していることから、表-6においてい 5 公園のサンプ ルを統合して集計した。

最も指摘数が多い「評価対象」は「広場」であり、回答者の約 4 割が 指摘している。「便所」、「ベンチ」、「樹木周辺」がこれに続き、約 3 割の回答者が「評価対象」として挙げている。これらの「評価対象」に 対応する「評価箇所」、および「污れの種類」をみるならば、「広場」で は、地面のごみや雑草が、「便所」では、床や便器への污れの付着に 関する指摘が多い。また、「ベンチ」では、ベンチ自体よりもむしろ その周辺部におけるごみの散乱に対する指摘が多いことがわかる。

\section{2 「評価対象」・「評価項目」の設定}

本研究では、施設等のなかでも、1 割以上の回答者により指摘さ れた対象である「広場」、便所」、「ベンチ小「樹木小「遊具小、砂場」、 「ごみ箱」の 7 つを「評価対象」と定義し、各「評価対象」において、「ど この（「評価箇所」）、何により（「污れの種類」）」評価されるのかと いった「評価項目」をそれぞれ 2 項目ずつ設定した。各「評価対象」に おける「評価項目」を表-7に示す。なお、右端に示した評価項目の指 摘数とは、各対象においてそれぞれの評価項目に対する指摘数を指 す。例えば、「ごみ箱」において、「(1)周辺のごみ」の指摘数が「12」と なっているが、この值は、表-6「ごみ箱（15）」のなかで、「指摘筒所」 が「周辺（12）」であり、かつ「污れの種類」が「ごみ（12）」と指摘し た人が 12 人であることを指す。

表-6 抽出した『評価のポイント』

\begin{tabular}{|c|c|c|c|c|c|}
\hline \multicolumn{6}{|c|}{ 表-6 } \\
\hline 評価対象 & 評価笽所 & 污れの種類 & 評価対象 & 評価箇所 & 污れの種類 \\
\hline \multirow[t]{7}{*}{ 広場(55) } & \multirow[t]{4}{*}{ 地面 (50) } & ごみ(35) & \multirow[t]{5}{*}{ ベン (40) } & 周辺(33) & ごみ(33) \\
\hline & & 雑草 (13) & & ベンチ自体(4) & 土埃(1) \\
\hline & & その他(1) & & & 落畕き(1) \\
\hline & & 無回答(1) & & & 無回答(2) \\
\hline & 周辺(2) & こみ(2) & & \multicolumn{2}{|c|}{ 無回答(3) } \\
\hline & 隅(3) & ごみ(2) & \multirow[t]{4}{*}{ 澍木周辺(36) } & 地面 (23) & ごみ(13) \\
\hline & & 雓草 (1) & & & 落ち莱(9) \\
\hline \multirow[t]{12}{*}{ 便所 (43) } & \multirow[t]{3}{*}{ 便器(9) } & 污れ(6) & & & 枝(1) \\
\hline & & ごみ(1) & & \multicolumn{2}{|c|}{ 無回管(13) } \\
\hline & & 無回答(2) & \multirow{4}{*}{ 遊真 (21) } & 触れる所 (11) & サビ(9) \\
\hline & \multirow[t]{2}{*}{ 床 $(9)$} & 污れ(5) & & & ペンキの剥がれ(2) \\
\hline & & ごみ(4) & & 周辺(2) & ごみ(2) \\
\hline & \multirow[t]{2}{*}{ 壁 (4) } & 落畫き (2) & & \multicolumn{2}{|c|}{ 無回答(8) } \\
\hline & & $\begin{array}{c}\text { 〈もの果(1) } \\
\text { 污れ(1) }\end{array}$ & 砂堵 (15) & 内(15) & $\begin{array}{c}\text { 和物の賚(11) } \\
\text { ごみ(4) }\end{array}$ \\
\hline & \multirow[t]{2}{*}{ 手洗い場(2) } & 水坛(1) & \multirow[t]{2}{*}{ ごみ箱(15) } & 周辺(12) & ごみ(12) \\
\hline & & 無回答(1) & & 中 (3) & ごみ(3) \\
\hline & 密(2) & ひび(2) & \multirow{3}{*}{\multicolumn{3}{|c|}{ ※)（）内の数値は指摘数を示す。 }} \\
\hline & その他(4) & 無回答(4) & & & \\
\hline & \multicolumn{2}{|c|}{ 無回答(13) } & & & \\
\hline
\end{tabular}


ここで、表-6 をみるならば、「広場」における「評価箇所」は、「地 面」といった全体を箇所と捉えた指摘と、広場の「周辺」や「隅」といっ た、一部の箇所を指摘したものが認められる。しかしながら、「周辺」 や「隅」といった箇所の明確な定義は困難であり、回答者によってイ メージする部分が異なると考えられる。以上のことから、地面に対 する部分的な指摘であるこれらの 2 箇所を「地面」に統合する。した がって、表-7 に示した「広場」の「評価項目」としては、「地面のご み」「地面の雑草」の 2 項目を設定した。また「便所」においては、「評 価箇所」が、「便器」、床」といった水平面に類する箇所、「壁」といっ た垂直面に類する箇所によって構成されていることから、「床、便器 の污れ・ごみ」・壁のクモの单・落書き」の 2 項目を設定した。「べ ンチ」では、「周辺」、「ベンチ自体」の简所で構成されていることから、 「周辺のごみ」・「ベンチ自体のホコリ・落書き」の 2 項目を、「樹木周 辺」においては、「地面のごみ」・「地面の落ち葉」の 2 項目を、「遊具」 においては、「触れる所のサビ・ペンキの剥がれ」・「周辺のごみ」の 2 項目をそれぞれ「評価項目」として設定した。「砂場」においては、 「内部の動物の糞」・「内部のごみ」の 2 項目を「評価項目」として設定 し、「ごみ箱」では、「周辺」、「中」の 2 箇所で構成されているため、「周 辺のごみ」・「中のごみの量」の 2 項目を「評価項目」とした。なお、こ こでは設定した「評価項目」のうち、指摘数の多いものを(1)、指摘数 の少ないものを(2)としている。

\section{3 評価基準の設定}

ここでは、前節で設定した各「評価対象」におけるそれぞれ 2 項目 の「評価項目」を用い、評価基隻を設定する。まず、各評価対象にお いて 3 段階により設定した評価基準を表-8 に示す。また、表-7 に示 した各「評価対象」における「評価項目」と評価基淮の対応を表-8 右 端に示す。

表-8 右端の評価項目(1)、(2)欄に付した○、×は、同段に示す評価 基準の記述において、表-7に示した評価項目 (1)、(2)に問題がない状 況 $(O) 、 も し く は$ 問題がある状況 $(\times)$ を意味している。なお、評 価基準の設定方法については既往研究 ${ }^{9)}$ を参考に、評価項目 (1)、(2) ともに問題ない状況をレベル 3（清掃品質・高）、評価項目(1)問題 はないが、(2)に問題がある状況をレベル2（清掃品質・中）、評価項 目（1)、(2)ともに問題がある状況をレベル1（清掃品質・低）とした。

例えば「広場」では、レベル $3:$ 「地面にゴミや雑草はほとんどみら れない。(1)「地面のごみ小、(2)「地面の雑草」ともに問題なし) 」、レ ベル 2:「地面にゴミはほとんど見られないが、雑草が見られる。(1) 「地面のごみ」に問題はないが、(2)「地面の雑草」に問題あり) 、、レベ ル 1:「地面にゴミや雑草がみられる。(1)「地面のごみ」、(2)「地面の 雑草」ともに問題あり)」となる。

\section{表-7 各評価対象における評価項目}

\begin{tabular}{|c|c|c|}
\hline 評価対象 & 評価項目 & 評価項目の指摘数 \\
\hline \multirow{2}{*}{ 広場 } & (1) 地面のごみ & 39 \\
\hline & (2) 地面の雑草 & 14 \\
\hline \multirow{2}{*}{ 便所 } & (1) 床、便器の污れ-ごみ & 16 \\
\hline & (2) 壁のクモの果·落書き & 3 \\
\hline \multirow{2}{*}{ ベンチ } & (1) 周辺のごみ & 33 \\
\hline & (2) ベンチ自体のホコリ-落書き & 2 \\
\hline \multirow{2}{*}{ 樹木周辺 } & (1) 地面のごみ & 13 \\
\hline & (2) 地面の落ち葉 & 9 \\
\hline \multirow{2}{*}{ 遊具 } & (1) 触れる所のサビ・ペンキの剥がれ & 11 \\
\hline & (2) 周辺のごみ & 2 \\
\hline \multirow{2}{*}{ 杪場 } & (1) 内部の動物の真 & 11 \\
\hline & (2) 内部のごみ & 4 \\
\hline \multirow[t]{2}{*}{ こみ箱 } & (1) 周辺のごみ & 12 \\
\hline & (2) 容器内のごみの量 & 3 \\
\hline
\end{tabular}

\section{6. 清掃品質の改善に関する検討}

ここでは、図-1における「V.清掃仕様の検討」段階において必要 となる知見を得るために、同図、II．III.により作成した調查票によ り実施した調査結果について分析を進める。具体的には、現状評価、 清掃要求度、および現在の清掃管理状況に対する満足度を明らかに したうえで、公園維持管理におう清掃品質の改善について検討す る。

\section{1 「評価対象」における使用頻度}

7 つの「評価対象」それぞれの使用頻度について、「よく利用する」 を 3 点、「たまに利用する」を 2 点、「ほとんど利用しないり 1 点に 得点化し、各「評価対象」の使用頻度（平均値）を算出した。結果を 表-9に示す。

3 公園を通じて最も使用頻度が高い対象は「ベンチ」であり、3 公園 の平均は 2 以上、すなわち「たまに利用する」以上の值を示した。ま た、広場」も 1.80 と高い值を示している。一方、「便所」、ごみ箱」 は、平均して 1.4 前後と他の対象と比較して低い值を示した。

公園ごとにみるならば、公園(1)において「広場」、「遊具」、「砂場」 の使用頻度が他の公園と比較して高くなっており、公園(3)では、「べ ンチ」において 2.48 と、他の対象と比較して值が突出している。

表-8 各評価対象における評価基準と評洒項目の対応

\begin{tabular}{|c|c|c|c|c|}
\hline \multirow{2}{*}{ 呯価対象 } & \multirow{2}{*}{ レベル } & \multirow{2}{*}{ 抨洒基染 } & \multicolumn{2}{|c|}{ 秤価項目 } \\
\hline & & & (1) & (2) \\
\hline \multirow{3}{*}{ 広埥 } & 3 & 地面にごみや雜草はほとんどみられない。 & 0 & 0 \\
\hline & 2 & 地面にこみはほとんどみられないが、雓草がみられる。 & 0 & $x$ \\
\hline & 1 & 地面にこみや雓草がみられる。 & $x$ & $x$ \\
\hline \multirow{3}{*}{ 便所 } & 3 & $\begin{array}{l}\text { 林や便器に污れやごみはほとんどみられず、壁のクモの果 } \\
\text { や落書きも目立たない。 }\end{array}$ & $\mathrm{O}$ & 0 \\
\hline & 2 & $\begin{array}{l}\text { 木や便器に污れやごみはほとんとみられないか、壁にはク } \\
\text { モの柴や落畫きがみられる。 }\end{array}$ & $\mathrm{O}$ & $x$ \\
\hline & 1 & $\begin{array}{l}\text { 床や便器に污れやごみがみられ、壁にもつ主の果や落毒き } \\
\text { がみられる。 }\end{array}$ & $x$ & $x$ \\
\hline \multirow{3}{*}{ ベンチ } & 3 & $\begin{array}{l}\text { ベンチ周辺にごみはほとんどみられず、ベンチ自体へのホコ } \\
\text { リなどの付㴋や落書きは目立たない。 }\end{array}$ & 0 & 0 \\
\hline & 2 & $\begin{array}{l}\text { ベンチ周辺にごみはほとんどみられないが、ベンチ自体には } \\
\text { ホコリなどの付㫊や落書きがみられる。 }\end{array}$ & 0 & $x$ \\
\hline & 1 & $\begin{array}{l}\text { だンチ周辺にこみみがみられ、ベンチ自体にもホコリなどの付 } \\
\text { 兼や落書きがみられる。 }\end{array}$ & $x$ & $x$ \\
\hline \multirow{3}{*}{ 樹木周辺 } & 3 & 措木の周辺にごみや落ち菜はほとんど見られない。 & $\mathrm{O}$ & $\mathrm{O}$ \\
\hline & 2 & $\begin{array}{l}\text { 榯木の周辺にごみはほとんどみられないか、落ち葉がみら } \\
\text { れる。 }\end{array}$ & 0 & $x$ \\
\hline & 1 & 榯木の周辺にごみや落ち蒾がみられる。 & $x$ & $x$ \\
\hline \multirow{3}{*}{ 遊鱼 } & 3 & $\begin{array}{l}\text { 手足の触れる所にサビやペンキの剥がれはほとんどみられ } \\
\text { ず、遊畳周辺のごみも目立たない。 }\end{array}$ & 0 & 0 \\
\hline & 2 & $\begin{array}{l}\text { 手足の螌れる所にサビやペンキの剥がれはほとんどみられ } \\
\text { ないか、、遊具周辺にはごみがみられる。 }\end{array}$ & 0 & $x$ \\
\hline & 1 & $\begin{array}{l}\text { 手足の螌れる所にサビやペンキの剥がれがみられ、遊具周 } \\
\text { 辺にもごみがみられる。 }\end{array}$ & $x$ & $x$ \\
\hline \multirow{3}{*}{ 砂堨 } & 3 & 砂場内に動物の賞やごみはほとんどみられない。 & $\mathrm{O}$ & $\mathrm{O}$ \\
\hline & 2 & $\begin{array}{l}\text { 砂場内に動物の畺はほとんどみられないが、こみがみられ } \\
\text { る。 }\end{array}$ & 0 & $x$ \\
\hline & 1 & 砂場内に動物の算やごみがみられる。 & $x$ & $x$ \\
\hline \multirow{3}{*}{ ごみ箱 } & 3 & $\begin{array}{l}\text { ごみ箱の周㲽にごみはほとんどみられず、中のごみもあまり } \\
\text { たまっていない。 }\end{array}$ & $\mathrm{O}$ & 0 \\
\hline & 2 & $\begin{array}{l}\text { ごみ箱の周辺にごみはほとんどみられないが、中にはごみ } \\
\text { がかなりたまっている。 }\end{array}$ & O & $x$ \\
\hline & 1 & $\begin{array}{l}\text { ごみ箱の周辺にごみがみられ、中にもごみがかなりたまって } \\
\text { いる。 }\end{array}$ & $x$ & $x$ \\
\hline
\end{tabular}

表-9 各調查対象公園における使用頻度

\begin{tabular}{c|c|c|c|c}
\hline 対象 & 公園(1) & 公園(2) & 公園(3) & 平均 \\
\hline 広場 & 1.90 & 1.75 & 1.66 & 1.80 \\
\hline 便所 & 1.45 & 1.39 & 1.34 & 1.41 \\
\hline ベンチ & 1.94 & 1.91 & 2.48 & 2.03 \\
\hline 樹木周辺 & 1.73 & 1.57 & 1.61 & 1.64 \\
\hline 遊具 & 1.92 & 1.54 & 1.34 & 1.66 \\
\hline 砂場 & 1.65 & 1.34 & 1.28 & 1.46 \\
\hline こみ箱 & 1.45 & 1.32 & 1.38 & 1.39 \\
\hline 年 & & & &
\end{tabular}




\section{2 現状評価と清掃要求度の比較検討}

各公園における現状評価と清掃要求度について比較検討するため、 現状評価を横軸、清掃要求度を縦軸にとり、各「評価対象」における 現状評価、および清掃要求度の平均評価得点について布置した。結 果を図-4に示す。なお、平均評価得点を算出するにあたり、レベル 3 を 3 点、レベル 2 を 2 点、レベル 1 を 1 点に得点化した。

現状評価をみるならば、「広場」「砂場」といった対象では、3 公 園を通じて比較的高い值を示す。また、「ごみ箱」、「遊具」、「ベンチ」 は、公園間における差異が大きく、かついずれの対象においても公 園(1)で最も低く、公園(3)で最も高い值を示している。

清掃要求度では、3 公園を通じて、「便所」、「砂場」といった対象 での要求が高く、「広場」、「樹木周辺」といった対象で低い值を示し ており、すべての対象において公園間での差異は小さい。

図示は省略するが、調查対象公園間の現状評価、および清掃要求 度それぞれの評価傾向を把握するため、7つの「評価対象」における 現状評価、および清掃要求度それぞれの平均評価得点により相関係 数を算出した結果、清掃要求度では、公園(1)-(2)間、公園(1)-(3)間、 公園(2)-(3)間のすべての組み合わせにおいて 0.92 以上の非常に強い 相関を示し、現状評価では、清掃要求度と比較して強い相関関係は みられないことから、現状評価は、各公園における清掃品質により 変化するが、清掃要求度は各公園の清掃品質の違いに関わらず、類 似した傾向を示すことを明らかにしている。

つぎに、現状評価と清掃要求度との評価の違いを明らかにするた めに両評価に対して $\mathrm{t}$-検定を適用した。なお、有意差が認められた

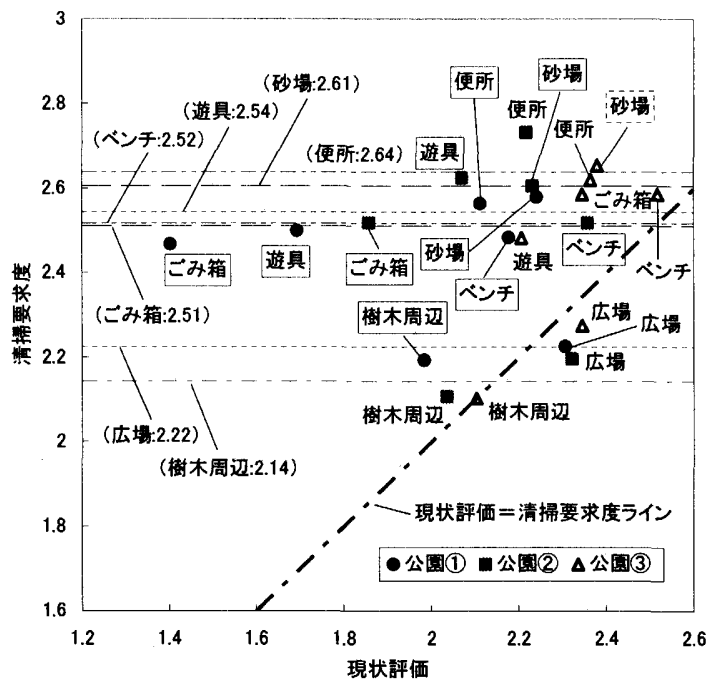

※1) 各公園において，現状評価と清渭要求度についてt一検定を行った結果， 有意水準1\%で有意となったものには実線、有意水準5\%で有意となったもの には点線で、图中のデータラベルに围線を施した。

※2) 图中に(謤洒対象:数徂)で示したラインは、それそれ各評洒対象における 清掃要求度の平均評価得点を 3 公園で平均した值を示す。

\section{図-4 現状評価と清掃要求度の関連}

表-10 清掃管理状況に対する満足度

\begin{tabular}{c|c|c|c|c}
\hline 評価対象 & 公園(1) & 公園(2) & 公園(3) & 平均 \\
\hline 㕕場 & 3.77 & 3.84 & 4.10 & 3.91 \\
\hline 便所 & 2.85 & 3.05 & 3.55 & 3.15 \\
\hline ベン千 & 3.24 & 3.46 & 3.79 & 3.50 \\
\hline 樹木周辺 & 3.61 & 3.63 & 4.07 & 3.77 \\
\hline 遊具 & 3.66 & 3.52 & 3.72 & 3.63 \\
\hline 砂場 & 3.39 & 3.09 & 3.59 & 3.35 \\
\hline ごみ箱 & 2.87 & 2.73 & 4.03 & 3.21 \\
\hline
\end{tabular}

対象にはデータラベルに囲線を施している。 $\mathrm{t}$-検定の適用により、 公園(1)では「広場」を除くすべての対象において有意水準 $1 \%$ で有意 差が認められ、公園(2)では「便所」、「遊具」、「砂場」、「ごみ箱」の 4 対象において有意差が認められる。また、公園(3において有意差が 認められたのは「砂場」のみである。さらに、これら有意差が認めら れた 11 対象においては、いずれも清掃要求度が現状評価を上回って いることから、これらの各対象においては、清掃品質の向上につい て具体的な検討を進める必要があるといえる。

\section{3 清掃管理状況に対する満足度}

各「評価対象」における現在の清掃管理状況に対する满足度につい て、「満足である」を 5 点、「やや満足である」を 4 点、「どちらともい えないを 3 点、「やや不満である」を 2 点、「不満である」を 1 点に得 点化し、各「評価対象」の満足度を算出した。結果を表-10に示す。

対象ごとにみれば、公園(1)の「便所了、および「ごみ箱小、公園(2)の「ご み箱」では、 3.0 末満、すなわち「どちらともいえないを下回る低い 值を示していることがわかる。これら 3 対象の現状評価をみるなら ば、公園(1)および(2)における「ごみ箱」の現状評価は、公園(3)を大き く下回り、公園(1)の「便所」も、3 公園のなかで最も低い評価を受け ていることがわかる。また、これらの結果と前節で示した現状評価 と清掃要求度の関連を併せてみるならば、これら 3 対象においては、 いずれも清掃要求度が現状評価を上回っており；かつ $\mathrm{t}$-検定の結果、 有意水準 $1 \%$ で両評価に有意差が認められている。

したがって、これらの対象においては、両評価に有意差が認めら れた 11 対象のなかでも、優先的に清掃品質の向上について具体的な 検討を進める必要があると考える。

\section{7. 結語}

近年、施設の維持管理に用いられる FM においては、達成目標 の一つとして、ライフサイクルのなかで、利用者要求に基づいた 改善を繰り返し実施することにより、利用者の満足度を常に高位 に維持することが挙げられる。，したがって、利用者による客観的 な評価も資産価值の向上を図るうえで重要な指標であると考える。 以上のような考え方に基づき、本研究においては、街区公園にお ける維持管理のなかでもその資産価值向上の一端を担うであろう 清掃管理に着目し、公園の利用者による清掃品質の現状評価にあ わせ、「どの程度きれいにしてほしいのか」といった清掃要求に関 する評価に基づいた清掃品質管理を可能とするために、利用者評 価による清掃品質管理手法」を提案した。また、本手法導入に向け たケーススタディではあるが、広島市佐伯区に位置する複数の街 区公園に対する本手法の適用から、図-1 に示したフローに則り、 「V.清掃品質の改善に関する検討」を行った。

『評価のポイント』に関する調査から、図-3に示す「総合的公 園」において、利用者が清掃品質を評価する際に着目する対象は、 主に「広場」、「便所」、「ベンチ小「樹木小、「遊具」、「砂場」、「ごみ 箱」の 7 つであることを明らかにした。さらにそれぞれの対象につ いて、「評価箇所」・「污れの種類」により構成される「評価項目」を それぞれ 2 種設定し、この 2 種をもとに 3 段階による評価基準を 作成した。

つぎに、作成した評価基淮により、清掃品質の評価に関する調 查を 3 公園で実施し、現在の清掃品質に対する「現状評価」「清掃 
要求度」および現在の清掃管理状況に対する満足度を明らかにした うえで、公園維持管理における清掃品質の改善について検討した。

そこでは、現状評価と清掃要求度の比較検討から、公園(1)では「広 場」を除くすべての対象において、公園(2)では「便所」、「遊具」、「砂 場」、ここみ箱」において、公園(3)では「砂場」において現状評価と清掃 要求度の間に有意差が認められ、いずれも清掃要求度が現状評価を 上回っていることを明らかにした。さらに、各対象における清掃管 理状況に対する満足度において、公園(1)では「便所」、「ごみ箱」が、 公園(2)では「ごみ箱」において、満足度が不満側に位置することから、 これらの対象では、清掃品質の向上について具体的な検討を進める 必要があることを明らかにした。ただし、本研究における評価は、 利用者の視点からみた『評価のポイント』によるため、直接的な品 質管理のあり方に言及できるものではない。例えば、樹木の管理形 態としては、日常的、または定期的な清掃以外にも、剪定、水遣り、 害虫駆除等が挙げられる。したがって、本研究で得られた知見に基 づき、その品質の改善、すなわち図-1 の「VI. 清掃仕様の検討」段階 において具体的な検討を進める際には、これら評価の向上に奇与す るであろう管理のあり方も含めた多角的な検討が必要である。

最後に、本論文の成果をふまえたうえで、さらに今後の展開につ いて述べる。

本研究では、各評価対象において、現状評価と要求する清掃品質 の間に乘離がある場合は、清掃品質の改善に向けた検討が必要であ ると解釈し、さらに各対象における清掃管理状況に対する満足度の 評価結果から、満足度が低い対象においては、清掃品質の改善につ いて優先的に検討する必要があると述べた。

しかしながら、両評価に乘離が認められた評価対象は 11 項目存在 するが、满足度評価が不満側に出た対象はそのうち 3 対象であるこ とから、今後、各評価対象それぞれにおける、現状評価と清掃管理 状況に対する満足度の関係についてさらなる検討が必要である。さ らに、表-8 に示した評価基準については、今後、調査対象公園にお ける清掃品質の改善による評価の変化量を把握したうえで、その妥 当性も含め、各「評価対象」に対する個別評価の変化が全体評価に与 える影響についてそれぞれ調查を実施する必要があると考える。

\section{謝辞}

調查研究に多大なご協力をいただいた調查対象公園の利用者の 方々に謝意を表します。また本研究は、広島大学 2005 年度卒論生、 三輪奈津子君に拹力いただきました。ここに謝意を表します。

\section{注}

注 1) 本研究において「施設等」とは、公園内に存在する便所などの施設、ベン チなどの設備のほか、植栽などの自然物を指す。

注 2) 本研究における「評価項目」は、「評価箇所」、「污れの種類」の組み合わせ により設定する。

注 3）1つの公園に同一用途の遊具が複数設置されていることは稀であり、遊 具の種類と用途別遊具数はほぼ一致することから、「遊具の種類」として 集計した。

注 4) 調查期間（11 月上旬）における利用者数は、目視による事前調查、およ び近隣住民へのヒアリングによって把握した。また、図-2より推察され る「総合的公園」の特徴は、数量化理論第而類に投入した 12 のアイテムが
「充足」側にあることである。これら 12 項目の特徴を「総合的公園」に分類 された 15 公園それぞれで集計した結果、いずれも 7〜10 項目を有してい ることを確認している。

注 5)利用者とは、目的を持って対象施設を訪れた来訪者を指し、単に対象施 設の敷地内を通過するものは含まない。

注 6) 公園をオープンスペースとして捉えた場合、利用者によりその領域認識 が異なる可能性があるため、評価の対象範囲は公園内に限定して実施し ている。

注 7)気温の低下により、『評価のポイント』に関する調查の実施時期 · (11月 上旬）と利用状況が異なる可能性があるため、各公園において 50 サンプ ルの収集を目標として、利用者数に関して目視による事前調査を「清掃品 質の評価に関する調查」(11 月下旬) の直前に再度実施した結果、その可 能性が高いと考えられる公園(1)〜(3)を調查対象とした。

注 8) 除草作業は、5〜10月に限り実施されている。

注9）各清掃作業の周期は、平成 13 年度に佐伯区が実施した街区公園清掃等報 奖金制度の状況調查によるが、各公園において清掃作業に参加している 近隣住民に対してヒアリングを行った結果、近隣住民による作業頻度は、 街区公園清掃等報奖金制度導入当時から現在に至るまで、ほぼ同様であ るとの回答を得ている。

\section{参考文献}

1)東京都建設局: 東京が切り拓く新時代の公園経営を目指して一パークマネジメン トマスタープランー, 2004. 8

2) 根来千秋, 渡辺達三: 児童公園等の管理における地域住民の参加・協力に関す る考察, 日本都市計画学会学術論文集, No.22, pp271-276, 1987.11

3) 井上ちひろ, 藍澤宏, 鈴木麻衣子: 都市居住地における街区公園・览童遊園の 管理方法に関する研究, 日本建築学会計画系論文集, No.578, pp9-15, 2004.4 4)樋野公厷, 小出治:住民による管理活動が公園の犯罪不安感に与える影響, 日 本建築学会計画系論文集, No.592,pp117-122, 2005. 6

5）塚田伸也，湯沢昭: 住民意識から捉えた小公園の評価構造に関する検討，日本 都市計画学会学術論文集, No.37, pp907-912, 2002.11

6)上杉知, 細見昭, 黒川洸: 犯罪不安感を考虑した住区基幹公園の利用選択に関 寸る研究, 日本都市計画学会学術論文集, No.34,pp61-66, 1999.11

7)清澤裕美, 安蘇秀徳, 茨木真, 井上雄二, 栗山恵都子, 坂下祥一, 庭田茂, 堀 口弘, 前川甲陽: 室内環境評洒基準作成のためのアンケート調査について(そ の1), 日本環境管理学会·室内環境学会合同研究発表会講演予稿集, pp136-139, 2004.10

8)坂下祥一, 安蘇秀徳, 井上雄二, 茨木真, 清澤裕美, 栗山恵都子, 庭田茂, 堀 口弘, 前川甲陽: 室内環境評価基準作成のためのアンケート調査について(そ の2), 日本環境管理学会·室内環境学会合同研究発表会講演予稿集, pp140-143, 2004.10

9)杉田洋, 佐藤隆良, 村川三郎, 平賀慎:琮舎におけるFM管理手法に基づいた清 掃発注仕様の品質評価に関する研究, 日本建築学会計画系論文集, No.600, pp161-169, 2006.2

10)国土交通省都市・地域公園緑地化監修:概説 新しい都市緑地法·都市公園 法, 2005.3

11)河瀬友香, 乙顔謙司, 総見陽介, 赤木徹也: 子共の遊び環境からみた公園の 構成一遊具を中心とした公園の配置特性に関寸研究 その 1一, 日本建築学 会大会学術講演梗概集, F-1 冊, pp1077-1078, 2005.9

12)讃井純一郎, 乾正雄:レパートリーグリッド発展手法による住環境評価構造の抽 出一認知心理学に基づく住環境評価に関する研究(1)一, 日本建築学会計画系 論文報告集, No.367, pp15-21, 1986

（2006年 3 月 10 日原稿受理，2006年 6 月13日採用決定） 